\title{
COSMIC PURPOSE AND THE QUESTION OF A PERSONAL GOD
}

\section{ANDREW PINSENT}

\author{
University of Oxford
}

\begin{abstract}
Purported evidence for purposeful divine action in the cosmos may appear to warrant describing God as personal, as Swinburne proposes. In this paper, however, I argue that the primary understanding of what is meant by a person is formed by the experience of ' $\mathrm{I}$ ' - 'you' or second-person relatedness, a mode of relation with God that is not part of natural theology. Moreover, even among human beings, the recognition of purposeful agency does not invariably lead to the attribution of personhood in the usual sense. 'Person' is therefore a misleading term to use of God on the evidence of cosmic purpose alone in the absence of suitable revelation.
\end{abstract}

\section{INTRODUCTION}

I begin with an extract from John Wisdom's influential paper 'Gods', published in the Proceedings of the Aristotelian Society in 1944:

Two people return to their long neglected garden and find among the weeds a few of the old plants surprisingly vigorous. One says to the other 'It must be that a gardener has been coming and doing something about these plants.' Upon enquiry they find that no neighbour has ever seen anyone at work in their garden. The first man says to the other 'He must have worked while people slept.' The other says 'No, someone would have heard him and besides, anybody who cared about the plants would have kept down these weeds' ... Each learns all the other learns about this [what happens to gardens generally without attention] and about the garden. Consequently, when after all this, one says 'I still believe a gardener comes' while the other says 'I don't' their different words now reflect no difference as to what they have found in the garden, no 
difference as to what they would find in the garden if they looked further and no difference about how fast untended gardens fall into disorder. ${ }^{1}$

Wisdom's 'parable of the gardener' achieved fame in the twentieth century principally through its reformulation in an article by Anthony Flew, 'Theology and Falsification', an article published initially in an undergraduate journal while Flew was still unambiguously an atheist. Flew gave the parable a more polemical edge than the original version, articulating the challenge in the starkest terms, 'Just how does what you call an invisible, intangible, eternally elusive gardener differ from an imaginary gardener or even from no gardener at all?'2 For Flew, therefore, theological utterances about purposeful divine action in the cosmos are incapable of falsification and endemically evil, a judgment that was described as continuing to haunt the discussion of religious language nearly three decades later. ${ }^{3}$

Perhaps surprisingly, considering that Wisdom offered a parable rather than a proof, responses to the challenge of falsification have often tacitly accepted the premise that the cosmos does in fact present an ambiguous face to those seeking evidence for divine action. ${ }^{4}$ In recent

${ }^{1}$ J. Wisdom, 'Gods', Proceedings of the Aristotelian Society, 45, New Series (January, 1944), 191-192.

${ }^{2}$ Flew's commentary was first published at Oxford in the first issue of an ephemeral undergraduate journal called University, which is now difficult to obtain, but the reprinted material can be found in Antony Flew and Alasdair C. MacIntyre, New Essays in Philosophical Theology (London: SCM Press, 1955), pp. 96-108. Flew gave the parable a polemical edge, describing explorers attempting to detect the gardener, whom no one has ever seen, by surrounding the clearing they have found with an electrified barbedwire fence and patrolling it with bloodhounds. Such additional elements were, of course, gratuitous: advocates of physicalism are, of course, perfectly content to accept invisible and intangible causal agents provided they are sufficiently regular and well-behaved: gravitational fields and neutrino beams being contemporary examples. Flew's views on God apparently changed later in life; see Antony Flew, There is a God: How the World's Most Notorious Atheist Changed His Mind, 1st ed. (New York: HarperOne, 2007).

3 Larry R. Churchill, 'Flew, Wisdom, and Polanyi: The Falsification Challenge Revisited', International Journal for Philosophy of Religion, 3, no. 3 (1972), 185.

${ }^{4}$ Hence in the years following Wisdom's paper, a great deal of work was done on the philosophy of perception and the gestalt that is sometimes associated today with righthemispheric cognition of the world. For some subtle early work on the philosophy of perception, see Michael Polanyi, Science, Faith and Society (London: Geoffrey Cumberlege, Oxford University Press, 1946). For an account of religious belief shaping a person's 'seeing as' experience of the world, see, for example, John Hick, God and the Universe of Faiths: Essays in the Philosophy of Religion (London: Macmillan, 1973), especially chap. 3. For neuroscientific evidence that may reinforce the importance of perceiving some kind 
decades, however, there have been some unexpected challenges to this assumption. In particular, contemporary physics has suggested that the relative values of many cosmic variables, their so-called 'fine-tuning', seem absurdly precise, rather as if the observers in Wisdom's parable have found that certain of the plants in the garden are growing in perfect rows, aligned to subatomic precision. As a consequence, although the reality and meaning of fine-tuning are still matters of fierce debate, the question of the discernment of divine, purposeful action in the cosmos has remained a surprisingly vigorous one. ${ }^{5}$

Without attempting to adjudicate this debate, I want in this paper to examine critically an inference that is often made or implied by the purported discernment of such action. Most discourses about a 'first cause' in natural theology or philosophy, such as an 'unmoved mover' or 'necessary ground of being' or 'that greater than which nothing can be conceived, do not in themselves convey any sense that this first cause could or should be described as personal. Cosmic purpose is different, since purpose is often associated with personal agency in daily life.

of gestalt as well as individual facts, see the account of the effects of right-hemispheric brain damage in Iain McGilchrist, The Master and his Emissary: the Divided Brain and the Making of the Western World (New Haven; London: Yale University Press, 2009), chap. 2. Note also Churchill's comment, that a believer, in order to communicate the difference made by a religious perspective on the world, will 'always and of necessity employ myths, parables, metaphors and sketches', that is, modes of discourse that communicate contextual frameworks and evoke embodied experiences: Churchill, 'Flew, Wisdom, and Polanyi: The Falsification Challenge Revisited', p. 185. Yet as contemporary talk of 'selfish' or 'selfless' genes and other examples testify, the association of the objects of science with grand narratives and metaphors that are not in themselves falsifiable is scarcely unique to a religious perspective and may be an important, even indispensable aspect of what it means to cognize the world in any kind of ordered manner. As examples of divergent grand narratives applied to similar scientific facts, see Richard Dawkins, The Selfish Gene: 30th Anniversary Edition, 3rd Revised ed. (Oxford: OUP, 2006) and Charles Foster, The Selfless Gene: Living with God and Darwin (London: Hodder \& Stoughton, 2009).

${ }^{5}$ For contrasting views and an overview of some of the strengths and weakness of the multiverse proposal, see Robert J. Spitzer, New Proofs for the Existence of God: Contributions of Contemporary Physics and Philosophy (Grand Rapids, Mich.; Cambridge, UK: William B Eerdmans Publishing Co, 2010) and Victor J. Stenger, Fallacy of Fine-Tuning (New York: Prometheus, 2011). For a good overview of the range of philosophical positions regarding fine-tuning, see Ernan McMullin, 'Anthropic Explanation in Cosmology', Faith and Philosophy, 22, no. 5 (2005): 601-614. It should be noted that theoretical physicists do tend to see fine-tuning as a 'problem' at present; see, for example, Lee Smolin, The Trouble with Physics: The Rise of String Theory, The Fall of a Science, and What Comes Next (New York: Houghton Mifflin Harcourt, 2006), especially chap. 11. 
In Wisdom's parable, for example, the invisible agent who may or may not be causing change in the garden is not a mere inanimate force, a living being or even some complex machine that weeds and waters automatically. A gardener, invisible or not, is a personal agent, applying abstract thought, combined with artistry to achieve some goal. When a garden shows evidence for such action, we therefore have no hesitation in classifying the agent responsible as 'someone' rather than 'something', to adopt Spaemann's phrase. ${ }^{6}$ Can the same inference be made for God? In other words, if the evidence shows that the cosmos has been put into an unexpectedly ordered state as a result of purposeful action by a rational agent, would it be reasonable to infer that this agent is also best described as 'someone' rather than 'something'?

Of course, one could simply define persons in terms of their capacity for rational, intentional action, as, for example, Swinburne does,

In personal explanation the occurrence of an event $E$ is explained as brought about by a rational agent or person $P$, having the intention $J$ to bring about $E$... Clearly the theist, in claiming that there is an omnipotent spirit, God, who makes or brings about (or permits the bringing-about of) all logically contingent things apart from himself, is using personal explanation. $^{7}$

In Swinburne's approach, it seems that a rational agent intending to bring about some state of affairs is a 'person', and God is therefore personal on the basis of divine action of this kind, but I fear that such a definition begs the question. In addressing this issue, however, I make the following caveats.

First, 'purposeful' action is an ambiguous concept, part of a broad spectrum of apparently teleological actions in nature. When ancient artefacts such as the Antikythera mechanism are discovered, we have no hesitation in concluding that these objects were deliberately designed and constructed for some purpose, yet the term 'purpose' is also frequently attributed to agents that are not normally regarded as persons.

${ }^{6}$ Robert Spaemann, Persons: The Difference Between 'Someone' and 'Something' (Oxford: Oxford University Press, 2006).

${ }^{7}$ Richard Swinburne, The Coherence of Theism, Rev. ed. (Oxford: Clarendon Press, 1993), pp. 137, 141-142. See also The Existence of God, 2nd ed. (Oxford: Clarendon Press, 2004), pp. 21, 35-45 in which Swinburne defines personal explanation as an explanation of a phenomenon as brought about intentionally by a rational agent, a 'person' who has 'at least the complexity of sensations, desires, beliefs, etc. typical of human beings'. 
Many non-human animals are naturally described as showing evidence of voluntary, 'purposeful' action and some even use tools to achieve complex goals. ${ }^{8}$ At a broader level of generalisation, even plants have been found to 'select' growth strategies to attain goals conducive to their flourishing, as in the case of the dodder plant that can distinguish wheat and tomato plants at a distance. ${ }^{9}$ At the broadest level of all, immanent end-directed action is increasingly recognised as an irreducible property of complex dynamical systems that are not even living. ${ }^{10}$

The only category of 'purpose' relevant for considerations of possible divine cosmic action, however, must be that which involves the understanding and selection of abstract principles and goals, such as those pertaining to the formal relations of purported fine-tuning. These kinds of purposeful actions are reasonably easy to identify when examining the actions of biological beings. Birds, for example, display great intelligence in navigation and building nests but they do not bury their dead, build astronomical mechanisms or construct their nests in the gothic style. To give another example, a rabbit may decide to eat a carrot, but not every third carrot. ${ }^{11}$ Such activities require understanding and intending abstract goals, capabilities that are, among animals, uniquely attributed to human and hence personal agency. The question is whether the same attribution of personal agency could also be made of God on the basis of purposeful action involving abstract principles and goals in the cosmos.

Second, the objection could be made that the notion of a person and a personal God first arose in the context of theology, specifically

\footnotetext{
8 The Antikythera mechanism is a highly complex artefact of some thirty interlocking bronze gears discovered northwest of Crete at the beginning of the twentieth century. Although there is still some doubt as to its intended use, there is no doubt that this artefact was brought about by a rational agent or agents who had the intention to create it for some purpose. See, for example, Derek De Solla Price, 'Gears from the Greeks: The Antikythera Mechanism - A Calendar Computer from ca. 80 B.C., American Philosophical Society, 64, no. 7 (1974), 1-70. For an argument that the term 'purpose' is also warranted in interpreting the actions of non-human animals, see, for example, Mary Midgley, 'Why the Idea of Purpose Won't Go Away', Philosophy: The Journal of the Royal Institute of Philosophy, 86, no. 338 (October 1, 2011), 545-561.

${ }^{9}$ Daniel Chamovitz, What a Plant Knows (Oxford: Oneworld Publications, 2012).

${ }^{10}$ See, for example, Gianfranco Basti, Filosofia Della Natura e Della Scienza, vol. I (Rome: Lateran University Press, 2002).

${ }^{11}$ The example of the bird building a nest in the gothic style is taken from Gilbert Keith Chesterton, The Everlasting Man (London: Hodder \& Stoughton, 1925), chap. 1. I am grateful to John Haldane for the example of a rabbit eating every third carrot.
} 
Christian revealed theology. ${ }^{12}$ Given that pre-Christian philosophy did not conclude that God is personal, it would seem plausible that natural theology would also fail to reach this conclusion more generally, if the doctrinal and cultural influences of revealed theology were stripped away. The response could be made, however, that the question is still an open one for two reasons. First, at least some of what is said of God in pre-Christian philosophy could be construed as personal language, such as, for example, the notion of following in God's company or friendship in Plato's later writings. ${ }^{13}$ Second, although historically the idea of a personal God developed from the working out of Christian revelation, this fact does not in itself rule out the possibility that such an insight might have been derived by natural reason alone in some other way, sooner or later.

Third, there are many on-going controversies surrounding the question of whether or not the notion of a personal God is coherent, drawing from the dissimilarities between God's existence and our own, such as atemporal versus temporal existence. ${ }^{14}$ In this paper, however, I restrict myself to a more basic issue. If divine action in the cosmos can be identified and if such action is purposeful, involving the selection of abstract principles and goals, is it reasonable to conclude on this basis that God is personal? If so, then a debate can still take place over the coherence of the term 'person' in the light of the other purported attributes of God, such as simplicity. If not, then it is unlikely that the question is going to arise anyway, since it is cosmic purpose that seems the most promising basis on which to conclude that God is personal on the basis of natural theology alone. Either way, examining the link between the discernment of purpose and the ascription of personhood is an important one.

\section{THE ASCRIPTION OF PERSONHOOD}

On what basis do we call some being a 'person'? A definition is not straightforward since persons are not a subdivision of some broader

\footnotetext{
12 'We began to speak of God as a person only when we began to speak of three persons in one God.' Spaemann, Persons, p. 40.

${ }^{13}$ See, for example, Plato, Laws, IV, 716a-b.

${ }^{14}$ For some recent criticisms of the coherence of the notion of a personal God, especially as presented in the arguments of Swinburne, see Herman Philipse, God in the Age of Science? A Critique of Religious Reason (Oxford: Oxford University Press, 2012), pp. 109-119.
} 
genus in the way in which man is a 'rational animal' in the biological world. Boethius' famous definition of a person as an individual substance of a rational nature has long been recognized as unsatisfactory and one cannot rely on equating being a person with being human if the issue to be examined is the personhood of God. ${ }^{15}$ Much contemporary philosophical discussion about persons is framed in terms of ethics, an example being Timothy Chappell's description of persons as belonging to the 'primary moral constituency.' ${ }^{16}$ With this focus, the main tasks of philosophical argumentation have been to determine the extent of application of the term 'person', starting from the basis that all or at least some human beings are 'persons', and to examine what this attribution means for ethical decisions. In these discussions, personhood is the 'whatever it is', if anything, that is added to being a human being to warrant the dignity of belonging to the 'primary moral constituency'. Contemporary discussions of whether certain higher animals can be considered 'persons' are essentially of the same kind, that is, ethical questions in disguise, and insofar as they give a definition of 'person' they tend to fall back on Locke's identification of personal identity with a distinct, persisting incommunicable consciousness. ${ }^{17}$ Such discussions do not, however, bring us any nearer to a resolution of the issue of whether God can be considered personal, since God is not a member of our species, or any species. Furthermore, even if Locke's approach to personal identity is not problematic in itself, it does not seem especially helpful for the problem at hand. Attempting to adjudicate on the personhood of God using the criterion of distinct, persisting incommunicable consciousness seems both inherently challenging and difficult to relate to purported evidence of cosmic divine action. Are there any other ways to address this question?

On this issue, I refer to Spaemann, who excels in highlighting the many peculiarities of the term 'person'. Persons, he notes, are not simply members of a class and 'do not share personhood as a common attribute,

${ }^{15}$ Boethius, De persona et duabus naturis, c. 2. For some early criticisms of Boethius' definition of a person by Richard of St Victor, see Spaemann, Persons, pp. 29-30.

${ }^{16}$ Timothy Chappell, 'On The Very Idea Of Criteria For Personhood', The Southern Journal of Philosophy, 49, no. 1 (2011), 1-27.

17 An example is the discussion of whether some animals could be considered as 'persons' in Peter Singer, How Are We To Live? Ethics in An Age of Self-Interest (Oxford: Oxford University Press, 1997), pp. 110-111. See also John Locke, Essay Concerning Human Understanding, II.27, 'Of Identity and Diversity' (1690). 
in the way that human beings share humanity' ${ }^{18}$ For example, there is no doubt that 'I' refers to something real, but,

When we say 'I', we are not referring to 'an Ego' - a pure invention of the philosophers! - but to a particular living creature, a particular human being identified by other speakers with the use of a personal name. But when this particular human being identifies the selfsame person that he or she actually is, the term 'I' is used. ${ }^{19}$

Spaemann goes on to point out various peculiarities with this selfidentification, notably that there is no unclarity about what 'I' refers to, regardless of any qualitative features whatsoever, even to the extent of someone forgetting who he is, robbed of memory and even forgetting that he is a human being. This latter point sets up an argument that being 'I' and being a human being are not simply interchangeable, a point reinforced by the fact that person (hupostatis) was specifically distinguished from having a nature (phusis) in the development of the early Christology and Trinitarian theology from which the concept of a 'person' first emerged. ${ }^{20}$ He also highlights the inherent uniqueness, subjectivity, singularity, irreducibility and incommunicability of the one who says ' $I$ ', from the perspective of the one who says this. This ' $I$ ' is a relational uniqueness, since, according to Spaemann, this is defined by a 'place' in the universe relative to everything else that can never be that person. ${ }^{21}$

These observations serve to underline how my own personhood, at least, is not something that is reducible to an objective state of affairs, even being a member of the human species, but what about the personhood of others, which is the key issue in addressing the question of the personhood of God? To what, or rather to whom - the distinctiveness of the grammar manifests the distinctiveness of the task - can 'I' or anyone else who self-identifies as 'I' ascribe personhood? Some clues from the language we use to denote persons may help to shed light on this problem. In many languages, the third-person forms are ambiguous, that is to say, the same grammatical structures can be used to describe the states of affairs of both personal and impersonal beings, and the reports of the actions of a distant agent may or may not lead us to infer that this agent is a person. The second-person forms are different. To use the

\footnotetext{
18 Spaemann, Persons, pp. 16, 62.

19 Ibid., p. 9.

${ }^{20}$ Ibid., pp. 10, 28.

${ }^{21}$ Ibid., p. 37.
} 
'you' form is to acknowledge that one is addressing a person, who is also irreducible and unique, and 'I' and 'you' are paired in language, a point to which Martin Buber famously drew attention. ${ }^{22}$

So what are the circumstances that shape the use of the second-person forms in grammar? This question is not easy because in the standard ways of expressing how we know others, that is, theorizing that a thing has a mind or a particular kind of internal causal structure, it is unclear how exactly 'it' becomes 'you', a point Jane Heal has mentioned. For this reason among others, some researchers have suggested that the origins of the distinctive second-person grammatical forms are to be found in varieties of interpersonal relatedness that precede the acquisition of language and which go under the name of joint attention. ${ }^{23}$ Examples of such interactions include pointing out objects to others, reciprocal smiling, lifting hands to be picked up and so on, activities that have been described as a 'sharing an awareness of the sharing of the focus' with another person, arguably the primordial mode of interpersonal communication in a human life. ${ }^{24} \mathrm{~A}$ close association of joint attention and second-person relatedness is also suggested by the fact that an inhibition of the former is often correlated with difficulties in learning and using the second-person forms of grammar correctly. ${ }^{25}$

Experiences of joint attention are not just important for shaping the use of the second-person form in grammar, however, but are, I suggest, the primary experiences for shaping our understanding of persons generally. As Iain McGilchrist has argued, every word, sooner or later, has 'to lead us out of the web of language, to the lived world, ultimately to ... something that relates to our embodied experience. ${ }^{26}$ In the case of the word 'person', when we hear or read this word, our understanding is shaped by our embodied experiences of persons. A plausible candidate for the most significant of these embodied experiences is second-person

${ }^{22}$ Martin Buber, Ich und Du, 1 aufl. (Leipzig: Insel-Verlang, 1923).

${ }^{23}$ See, for example, Jane Heal, 'Joint Attention and Understanding the Mind', in Joint Attention: Communication and Other Minds: Issues in Philosophy and Psychology, ed. by Naomi Eilan et al. (New York: Oxford University Press, 2005), pp. $34-44$ (p. 41).

${ }^{24}$ Naomi Eilan, 'Joint Attention, Communication, and Mind', in Eilan et al., Joint Attention, pp. 1-33. The phrase 'sharing an awareness of the sharing of the focus' is from Peter Hobson, 'What Puts Jointness into Joint Attention?', also in Joint Attention, pp. 185-204 (p. 185).

${ }^{25}$ Andrew Pinsent, The Second-Person Perspective in Aquinas's Ethics: Virtues and Gifts (New York; Abingdon, UK: Routledge, 2012), pp. 47-49.

${ }^{26}$ McGilchrist, The Master and his Emissary, p. 116. 
relatedness or joint attention, since these experiences are uniquely with other persons, play a crucial role in human development from a very young age and continue throughout life for as long as a person is in any kind of social setting. All kinds of other experiences may, of course, be associated with the term 'person', but it is, I suggest, this experience of relating as an 'I' to a 'you' that is primary for most of us in grounding the meaning of the word and which also, it has been argued, underpins much of the ethical significance of the term 'person. ${ }^{27}$

At first glance, therefore, it seems that any possibility that God can be regarded as personal on this basis can and should be dismissed within natural theology. God's divine nature is spiritual and is not present to our senses the way that human persons are. In addition, the kinds of activities that might be interpreted as enabling second-person relatedness to God by other means, such as inspired narratives, covenants, liturgies, and modes of relation associated with the Incarnation, seem to be exclusively the prerogative of revealed or supernatural theology. ${ }^{28}$ Moreover, even the use of second-person forms to address God is uncommon in classical philosophical texts that refer to divine matters, in marked contrast to the frequent use of 'you' to denote God in later Christian writings, such as those of Augustine. These structural and grammatical differences arguably underline that second-person relatedness to God pertains exclusively to revealed theology. ${ }^{29}$

Nevertheless, the situation is not entirely hopeless. There are many human beings, for example, whom we have never met and may never meet, who we still regard as persons insofar as we are members of the same species, the typical perfection of which includes the ability to relate in a second-personal way as circumstances allow. Moreover, our experience of persons also teaches that those beings to whom we relate second-personally are also the ones uniquely capable of abstract reasoning and goals. Given that all the beings that we know to be capable

${ }^{27}$ A recent argument for the importance of second-person relatedness in grounding ethics is Stephen Darwall, The Second-Person Standpoint: Morality, Respect, and Accountability (Cambridge, Mass.; London: Harvard University Press, 2006).

${ }^{28}$ For a recent study of key Scriptural narratives interpreted in the light of secondperson relatedness to God and others, see Eleonore Stump, Wandering in Darkness: Narrative and the Problem of Suffering (Oxford: Clarendon Press, 2010).

${ }^{29}$ Classical texts tend to refer more or less exclusively to God in the third-person, for example, Aristotle, Metaphysics, XII, 7, 1072b14-30. By way of contrast, see, for example, the famous prayer, 'Late have I loved you', in Augustine, Confessions of St. Augustine, Books I-X, trans. Francis J. Sheed (New York: Sheed \& Ward, 1942), X.27. 
of such reasoning are also personal beings, is there any warrant for describing God as personal on the same basis, namely the discernment of purposeful divine action involving abstract reasoning in the cosmos?

Adjudication is not easy, because agents capable of abstract reasoning and goals are almost invariably identified as persons in the normal way, to the extent that it may be hard to imagine an alternative classification. Nevertheless, some intriguing exceptions have emerged from recent work in experimental psychology. Peter Hobson describes an experiment that tested sixteen children and adolescents with autism and sixteen others without autism who were similar in age and linguistic ability. These children were shown an experimenter performing a variety of actions with some simple objects and, at a later time, they were given the same objects and asked to use them. Although most of the children repeated most of the actions they had seen the experimenter perform, a marked difference emerged as to how they used the objects. In Hobson's words,

The children without autism were imitating the person of the experimenter, and in so doing they assumed his style as well as his approach to accomplishing each goal. The children with autism watched and imitated the action rather than the person doing the action. ${ }^{30}$

Those with autism therefore cognized the purposeful actions of these agents to the point of being able to imitate their actions readily, but they did not cognize the agents as persons in the normal way.

Some caveats and clarifications are needed. Those with autism do not have any particular difficulty in recognising that persons are unique kinds of beings in the world, and perform just as well as those without autism in distinguishing persons from non-persons. ${ }^{31}$ Those with autism do not, however, generally engage in joint attention activities such as pointing and, as they learn language, they have a peculiar difficulty in using the 'I' and 'you' forms in grammar correctly, a phenomenon known as pronoun reversal. ${ }^{32}$ As a result, the primary metaphoric understanding of the term

${ }^{30}$ Hobson, 'What Puts Jointness into Joint Attention?', p. 200.

${ }^{31}$ Ibid., p. 191.

${ }^{32}$ Leo Kanner, 'Autistic Disturbances of Affective Contact', Nerv. Child, 2:220 (1943); reprinted in Leo Kanner, 'Autistic Disturbances of Affective Contact', Acta Paedopsychiatrica, 35 , no. 4 (1968), 100-136. For a comparison of pronoun reversal in autistic and Down's syndrome children, see, for example, Helen Tager-Flusberg, 'Dissociations in Form and Function in the Acquisition of Language by Autistic Children: Studies of Atypical Children', in Constraints on Language Acquisition: Studies of Atypical Children, ed. by Helen TagerFlusberg (Hillsdale, N.J.; Hove: Erlbaum, 1994), pp. 174-194 (p. 184). 
'person' that is, for most of us, drawn from the experience of secondperson relatedness, is absent from their worldview, an absence manifested in the way they are sometimes described as not 'seeing' persons at all..$^{33}$

What is striking about these results is that the situations being described involve only human persons carrying out human actions in human ways, and yet the recognition of purposeful agents does not invariably lead to an ascription of personhood in the way that the term 'person' is understood typically. In the case of cosmic divine action, the situation is disproportionately more challenging. Even if we discern the intelligent order we expect of purposeful action, perhaps with the bonus of perceiving a certain artistry in the cosmos - as might be claimed of the elegance of the laws of physics or of beautiful fractal structures such as the Mandelbrot Set - this is not the same as discerning the purpose. ${ }^{34}$ Indeed, many theists and atheists concur that what the divine purpose is or even whether this purpose is good in terms of ultimate human (or other) flourishing are notoriously difficult to determine on the basis of our natural knowledge of the world alone..$^{35}$ Moreover, if there is a God who has acted in a purposeful manner in creation, the ways in which any such purposes are achieved seem, to the best of our knowledge, very different to the ways in which human persons go about achieving their goals.

So there seems to be little warrant for describing God as personal on the basis of the discernment of purposeful action in the cosmos alone. The use of the term 'person' may even be misleading, since the metaphoric understanding of the word is shaped by experiences of second-person relatedness that are inapplicable to a relationship to God in the absence of divine help. If there is any hope of connecting the

${ }^{33}$ Clara Claiborne Park, The Siege: The First Eight Years of an Autistic Child (With an Epilogue, Fifteen Years After) (Boston, London: Little, Brown and Company, 1982), p. 93.

${ }^{34}$ Heinz-Otto Peitgen and Peter H. Richter, The Beauty of Fractals: Images of Complex Dynamical Systems (Berlin: Springer-Verlag, 1986).

${ }_{35}$ As an example from a theistic perspective, Newman claims that we cannot gain knowledge of God's purposes simply from the study of the cosmos, as shown by his claims in the following passage, 'Religion, it has been well observed, is something relative to us; a system of commands and promises of God towards us. But how are we to be concerned with the sun, moon, and stars? Or with the laws of the universe? ... They do not speak to sinners at all. They were created before Adam fell. They "declare the glory of God", but not his will.' See John Henry Newman, 'Sermon XXIV: The Religion of the Day', in Parochial and Plain Sermons: Volume I, New ed. (London; New York: Longmans, Green, 1891). As an example from an atheistic perspective, see Philipse, God in the Age of Science?, pp. 256-278. 
discernment of cosmic purpose with the discernment of the personhood of God, the most promising approach may in fact work in the opposite direction. Cultures shaped by the revelation of a personal God with whom second-person relatedness is possible may tend to perceive the cosmos in certain beneficial ways, for example with the expectation that it is ordered and that at least some aspects of this order can be known by us. Such a perspective seems prima facie to be a more promising starting point than a deep-rooted belief in cosmic disorder, accidental order, or a remote and unknowable deity. ${ }^{36}$ An argument may then be possible that resembles Pascal's wager, insofar as a commitment to faith in a personal God may be seen to be a fruitful cultural wager for understanding and representing the natural world, for example in art. ${ }^{37}$ Nevertheless, such a method is at best likely to yield only certain fruitful signs rather than anything approaching a rigorous proof.

${ }^{36}$ For an early example of this perception of cosmic order in the light of revelation, see, for example, this text from what is perhaps the earliest authentic Christian document outside of the New Testament, the First Letter of Clement, 20, 'The heavens, revolving under his government, are subject to him in peace. Day and night run the course appointed by him, in no wise hindering each other. The sun and moon, with the companies of the stars, roll on in harmony according to his command, within their prescribed limits, and without any deviation. The fruitful earth, according to his will, brings forth food in abundance, at the proper seasons, for man and beast and all the living beings upon it, never hesitating, nor changing any of the ordinances which he has fixed.' Note that at end of the first century, when the Christian community was small and threatened, this letter communicates a surprising sense of the order and harmony of the cosmos on the grandest scales in the light of the new Christian revelation. The translation is from James Donaldson and Alexander Roberts, eds., The Apostolic Fathers with Justin Martyr and Irenaeus, vol. I, Ante-Nicene Christian Library: Translations of the Writings of the Fathers down to A.D. 325 (Edinburgh: T\&T Clark, 1867).

37 Correlation is not, of course, causation and a variety of narratives could be told to explain the same facts about the fruitfulness or otherwise of a culture, but art is instructive because it provides an insight into the context or gestalt, often shaped by faith, within which the world is cognized by a society. Second-person relatedness to God as a theme of art, with nature perfected, is a central theme of Van Eyck, Ghent Altarpiece or The Adoration of the Mystic Lamb, completed in 1432. The emphasis on the themes of revelation gradually faded in the sixteenth century, a transition seen in Joachim Patinir, The Penitence of St Jerome, completed c. 1518, and Pieter Bruegel the Elder, The Harvesters, in 1565. In later centuries, themes of nature alone often dominate, as in Constable, The Hay Wain, 1821, but disintegration of form and loss of hope sets in at least by the time of Van Gogh, Wheatfield with Crows, painted in 1890 and Pollock, Enchanted Forest, painted in 1947, which has no discernible features left. On balance, the earlier faith-based perspectives on the world, rooted in second-person relatedness to God, seem to have inspired greater order and beauty than their less faith-based successors. 


\section{CONCLUSION}

Although we are justified in attributing the production of sophisticated artefacts, showing evidence of abstract reasoning and goals, to personal agency, this attribution is only ever indirect, namely that such artefacts are thereby revealed as being the work of human beings and hence of persons such as ourselves. In the case of God, no such attribution can be made, since God is not, by divine nature, a member of our species or any species. Moreover, even if we succeed in uncovering evidence for purposeful divine action in the cosmos, involving abstract reasoning and goals, the term 'person' is only justified thereby in a Swinburnian sense. Since the meaning of the term 'person' is shaped, for most of us, primarily by the experience of second-person relatedness, the attribution of personhood, whether to other human beings or to God, cannot follow simply from evidence of purposeful agency if there is no pre-existing capacity for second-person relatedness with the agent concerned. In the case of God, such a capacity can only come about as a divine gift. Hence, evidence of cosmic purpose does not in itself warrant us concluding that God is personal in the absence of such a gift. ${ }^{38}$

\section{BIBLIOGRAPHY}

Augustine, Confessions of St. Augustine, Books I-X. Translated by Francis J. Sheed (New York: Sheed \& Ward, 1942)

Basti, Gianfranco, Filosofia Della Natura e Della Scienza. Vol. I (Rome: Lateran University Press, 2002)

Buber, Martin, Ich und Du. 1 aufl. (Leipzig: Insel-Verlang, 1923)

Chamovitz, Daniel, What a Plant Knows (Oxford: Oneworld Publications, 2012) Chappell, Timothy, 'On The Very Idea Of Criteria For Personhood', The Southern Journal of Philosophy, 49, no. 1 (2011), 1-27

Chesterton, Gilbert Keith, The Everlasting Man (London: Hodder \& Stoughton, 1925) Churchill, Larry R., 'Flew, Wisdom, and Polanyi: The Falsification Challenge Revisited', International Journal for Philosophy of Religion, 3, no. 3 (1972), 185-194

Darwall, Stephen, The Second-Person Standpoint: Morality, Respect, and Accountability (Cambridge, Mass.; London: Harvard University Press, 2006)

Dawkins, Richard, The Selfish Gene: 30th Anniversary Edition, 3rd Revised edition (Oxford: Oxford University Press, 2006)

38 This paper was originally presented in Munich, at a conference for the Analytic Theology Project, generously funded by the John Templeton Foundation. 
Donaldson, James, and Alexander Roberts, eds. The Apostolic Fathers with Justin Martyr and Irenaeus, Vol. I. Ante-Nicene Christian Library: Translations of the Writings of the Fathers down to A.D. 325 (Edinburgh: T\&T Clark, 1867)

Eilan, Naomi, Christoph Hoerl, Teresa McCormack, and Johannes Roessler, eds. Joint Attention: Communication and Other Minds: Issues in Philosophy and Psychology (Oxford: Clarendon Press, 2005)

Eilan, Naomi, 'Joint Attention, Communication, and Mind', in Eilan et al., eds. Joint Attention, pp. 1-33

Flew, Antony, There is a God: How the World's Most Notorious Atheist Changed His Mind, 1st ed. (New York: HarperOne, 2007)

Flew, Antony, and Alasdair C. MacIntyre, New Essays in Philosophical Theology, (London: SCM Press, 1955)

Foster, Charles, The Selfless Gene: Living with God and Darwin, (London: Hodder \& Stoughton, 2009)

Heal, Jane, 'Joint Attention and Understanding the Mind', in Eilan et al., eds. Joint Attention, pp. 34-44

Hick, John, God and the Universe of Faiths: Essays in the Philosophy of Religion, (London: Macmillan, 1973)

Hobson, Peter, 'What Puts Jointness into Joint Attention?', in Eilan et al., eds. Joint Attention, pp. 185-204

Kanner, Leo, 'Autistic Disturbances of Affective Contact', Acta Paedopsychiatrica, 35, no. 4 (1968), 100-136

McGilchrist, Iain, The Master and his Emissary: the Divided Brain and the Making of the Western World (New Haven; London: Yale University Press, 2009)

McMullin, Ernan, 'Anthropic Explanation in Cosmology', Faith and Philosophy, 22 , no. 5 (2005), 601-614

Midgley, Mary, 'Why the Idea of Purpose Won't Go Away', Philosophy: The Journal of the Royal Institute of Philosophy, 86, no. 338 (October, 2011), 545-561

Newman, John Henry, 'Sermon XXIV: The Religion of the Day', in Parochial and Plain Sermons: Volume I, New ed. (London; NY: Longmans, Green, 1891)

Park, Clara Claiborne, The Siege: The First Eight Years of an Autistic Child (With an Epilogue, Fifteen Years After) (Boston, London: Little, Brown and Company, 1982)

Peitgen, Heinz-Otto, and Peter H. Richter, The Beauty of Fractals: Images of Complex Dynamical Systems (Berlin: Springer-Verlag, 1986)

Philipse, Herman, God in the Age of Science? A Critique of Religious Reason (Oxford: Oxford University Press, 2012)

Pinsent, Andrew, The Second-Person Perspective in Aquinas's Ethics: Virtues and Gifts (New York; Abingdon, UK: Routledge, 2012)

Polanyi, Michael, Science, Faith and Society (London: Geoffrey Cumberlege, Oxford University Press, 1946) 
Price, Derek De Solla, 'Gears from the Greeks: The Antikythera Mechanism - A Calendar Computer from CA. 80 B.C.', American Philosophical Society, 64, no. 7 (1974), 1-70

Singer, Peter, How Are We To Live? Ethics in An Age of Self-Interest (Oxford: Oxford University Press, 1997)

Smolin, Lee, The Trouble with Physics: The Rise of String Theory, The Fall of a Science, and What Comes Next (New York: Houghton Mifflin Harcourt, 2006)

Spaemann, Robert, Persons: The Difference Between 'Someone' and 'Something' (Oxford: Oxford University Press, 2006)

Spitzer, Robert J., New Proofs for the Existence of God: Contributions of Contemporary Physics and Philosophy (Grand Rapids, Mich.; Cambridge, UK: William B. Eerdmans Publishing Co., 2010)

Stenger, Victor J., Fallacy of Fine-Tuning (New York: Prometheus, 2011)

Stump, Eleonore, Wandering in Darkness: Narrative and the Problem of Suffering (Oxford: Clarendon Press, 2010)

Swinburne, Richard, The Coherence of Theism, Rev. ed. (Oxford: Clarendon Press, 1993)

Swinburne, Richard, The Existence of God, 2nd ed. (Oxford: Clarendon Press, 2004) Tager-Flusberg, Helen, ed., Constraints on Language Acquisition: Studies of Atypical Children (Hillsdale, N.J.; Hove: Erlbaum, 1994)

Wisdom, J., 'Gods', Proceedings of the Aristotelian Society, 45, New Series (January, 1944), 185-206 